\title{
NEGERS IN AMERIKA
}

\author{
DOOR
}

\author{
C. H. DE GOEJE
}

Een opstel van $\mathrm{Ph}$. A. SAmson, Afgoderij als strafbaar feit (De West-Indische Gids 1946, pp. 378-81) heeft weer eens de aandacht gevestigd op iets dat schier overal voorkomt bij mensen van Afrikaanse afkomst op Amerikaansen bodem, n.l. de religieuse bezetenheid.

De Surinaamse Neger zegt het zelf: in zo'n toestand is men het hasi (paard) van een winti; ook op Haït is deze, uit Afrika afkomstige, beeldspraak in zwang. En winti beduidt ,,geest”, n.l. het levensbeginsel van iets in de natuur, dat zich op de wijze van een psychisch complex in een mens manifesteert.

Het Negerengels woord winti wordt ook gebezigd om ,wind" aan te duiden; dit doet denken aan het Latijn, waarin spiritus aanduidt het geblaas van den wind, doch ook een geest en geestvervoering, en anima wind, adem en levensbeginsel. Inplaats van winti gebruikt de Bosneger het woord gad $u$ ( $u$ Ned. oe-klank) $=$ god. Op Haïti noemt men zulke geesten loa of $l o i$, vermoedelijk van Frans ro $i=$ koning; op Cuba en in Brazilië worden zij santo $=$ heilige, genoemd.

Met het in Suriname strafbaar gestelde ,plegen van afgoderij” wordt in het bijzonder bedoeld het in gemeenschap zich overgeven aan die religieuze bezetenheid, veelal op de wijze van dans begeleid door neger-trommen. Het is een soort rituaal, dat i.h.a. ten doel heeft de betrokken geesten (goden) gunstig te stemmen. Dat was bijv. het geval bij een gado pré (goden-spel = winti-dans) dat wij in 1907 te Drietabbetje bijwoonden. Bij het schoonbranden van bos om een kostgrond (akker) aan te leggen, had men, zonder het te willen, een heilige papa-slang (boa-soort) gedood, en allerlei verschijnselen wezen erop, dat de $p a p a$-god verstoord was. De dans zou hem verzoenen (Verslag der Toemoekhoemakexpeditie, Tijdschr. K. N. Aardr. Gen. 1908).

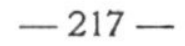


Wie het aanschouwt, bemerkt dat de deelnemers werkelijk in een bijzonderen toestand verkeren. Moge er misschien wel eens gekunstelde geestvervoering zijn, over het algemeen is het ,,echt”, en deelnemers en publiek zijn overtuigd van de werkelijkheid en hechten eraan. Geestig is wat Herskovits (Suriname Folk-Lore, p. 93) vertelt: een oude man die de trom bespeelde, rieptoen verscheidenen bezeten werden: Presi Gado, afkodrai a no dede yete! (geloofd zij God, afgoderij is nog niet dood!).

Psychische toestanden waarbij de betrokkene als een medium is, hebben vroeger een zeer belangrijke rol gespeeld. In berichten uit de oudheid wordt er dikwijls melding van gemaakt en in latere tijden is het bij schier alle primitieve of half-primitieve volken aangetroffen. De onderstelling dat het pathologische verschijnselen zouden zijn, moge in enkele gevallen juist zijn, in haar algemeenheid is zij vermoedelijk onjuist.

De Kariben en Arowakken (Indianen) gebruiken om zich in trance te brengen o.a. het sap van den takini-boom, en hoewel de Negers andere methoden hebben, noemen zij dezen boom mama-wodu, d.i. de moeder van wodu. Wodu nu, is vrij zeker hetzelfde als Dahomey (Afrika) vodu, de generieke naam voor geest of god, en in de U.S.A. is vodu (gespeld voodoo) een verzamelnaam voor alle soort neger-bijgeloof en daarmede verband houdende praktijken. Er bestaat ook een roman van Gustav MEYRINK, Das grüne Gesicht, spelend te Amsterdam omstreeks 1920, waarin een der hoofdpersonen is een Zulu-neger, priester van de vid $\hat{u}$-slang, een groene geestslang met mensengezicht.

Met die geesten moet men terdege rekening houden; alles wat er in de natuur geschiedt en alle goed en kwaad in het menselijk leven, komt door hun tussenkomst tot stand. Overal bij volken der oudheid en bij primitieven en half-primitieven is er de overtuiging dat men zich van de natuurgeesten, d.i. van psychische natuurkrachten, kan bedienen; dat is hetgeen wij met het woord „magie” aanduiden. En overal kent men het aanwenden dier magie voor goede, doch ook voor slechte, egoïstische, doeleinden. In Suriname is het de obia-man of gadu-man die goede magie verricht, de wisi-man die boze magie verricht. Obia (ook in Brits West-Indië) is vermoedelijk een Afrikaans woord (Ashanti obayi?), wisi komt vermoedelijk van Engels witch of wizardy. Op Jamaica heeft obia-man een ietwat ongunstige betekenis, myal-man een gunstiger betekenis.

Gelijk alle magie was ook dit Neger-bedrijf hoogst waarschijnlijk slechts de technische toepassing van het eerstehands weten 
van den primitieven mens. Of het nog immer door werkelijk helderzien of ware ingeving wordt gesteund, staat echter te betwijfelen. Wat van deze praktijken bekend is, lijkt veeleer een proberen en fantaseren door lieden die er niet meer het fijne van weten, en dikwijls laat men er zich goed voor betalen of vordert een andere beloning. In Suriname heet zo iemand ook wel luku$\operatorname{man}=$ zien-man, ziener.

Gelijk gezegd, is dé afgoderij in Suriname strafbaar gesteld, en dat was ook al zo in den slaventijd, en eveneens in andere landen. Lieden die in een toestand van geestvervoering verkeren, heeft men niet meer in de hand, vgl. het Mohamedaanse dhikr (dikir). Het geloof van betrokkenen dat zij onkwetsbaar zouden zijn, maakt het nog gevaarlijker. Hostman schreef hierover (1850): ,,.... dat de voorstanders van dit bijgeloof, hetwelk veel naar krankzinnigheid zweemt, niettegenstaande zij in functie altijd dronken zijn, onder de Negers veel vertrouwen bezitten; dat de geestverrukkingen, waartoe zij zich met behulp van drank weten op te winden, groten indruk op de belijders daarvan maken, en dat de uitspraken, die zij in dergelijken dronken toestand doen, op huns gelijken veelal de kracht van orakels, van godspraken bezitten, en niet alleen voor bijzondere personen, maar ook voor het algemeen de noodlottigste gevolgen kunnen hebben. Het is om deze reden, dat dergelijke afgoderij in vroegere tijden bij zware straffen verboden was."

In verscheidene Amerikaanse landen (echter, v.z.v. mij bekend, juist niet in Suriname) heeft de zaak nog een andere wending genomen, doordien in den Afrikaansen godsdienst RoomsKatholieke elementen zijn opgenomen (syncretisme). Bepaalde geesten worden gelijkgesteld met R. K. heiligen, engelen of nog hoger machten. Bijv. in Recife (Brazilië), de Afrikaanse god Ogun met St. Paulus en in Rio de Janeiro met St. George; de god Orixala in Bahia met Senhor do Bomfin. Bij het rituaal ziet men dan ook, in Brazilië en op Haïti nevens allerlei Afrikaanse objecten, R. K. beeltenissen van heiligen enz. In Brazilië is er ook vermenging met Mohamedaanse elementen. Indiaanse elementen spelen in het Negergeloof geen, of bijna geen rol.

In Afrika waren de magisch-religieuse praktijken soms nogal bloedig; ook Haïti staat ten deze in een kwaden reuk. Op Haïti zijn de Negers en mulatten anderhalve eeuw geleden, onder begunstiging der Franse revolutie, ,,vrij”" geworden. Ook daarbij en bij de nadien gekomen politieke verwikkelingen is, tot in recenten tijd, veel gemoord. Moord uit politieke overwegingen konden wij 
in modernst Europa van nabij bekijken. Hier was het veelal dat mensen onder den invloed van dwangdenkbeelden, van een psychose, handelden. De overeenkomst met primitieve volken werd nog duidelijker, als men acht sloeg op de werkelijk magische methoden der propaganda. Merkwaardigerwijze geschiedde dit soms onder de leuze van vrijheid!

De Negers hebben in de Nieuwe wereld wel de taal hunner meesters aangenomen, doch de Neger-creoolse talen zijn (volgens Herskovits) eigenlijk een vertaald Afrikaans. Er zijn ook, en in het bijzonder op het terrein van religie en aanverwante zaken, veel Afrikaanse namen in zwang gebleven. Een greep uit vele: Lebba $=$ de geest der kruiswegen, akra of $k r a=$ de levensgeest van den mens, iets dergelijks als de $k a$ der oude Egyptenaren. Ook het woord bakra of bakara in Suriname, op Jamaica en in South Carolina buckra =een Blanke. Volgens een Amerikaans woordenboek betekent buckra white, or belonging to the white men; hence good; strong. 1 white man, master, 2 Old Calabar (in de bocht van Guinea) A powerful demon.

Echt Afrikaans is het gebruik om bij het feest dat ten doel heeft de ziel van een overledene tot rust te brengen, Anansi-tori's, te vertellen, dat zijn geschiedenissen van Anansi, de slimme spin, een Afrikaans woord. Deze geschiedenissen zijn buitengewoon geestig. Men geeft elkaar ook raadsels op. En de Neger is een virtuoos in pittige spreekwoorden. Voeg daarbij nog aanleg voor muziek, dan heeft men reeds een indruk van het genie van den Neger.

Een ander verschijnsel, dat in verschillende streken genoteerd werd, is dat de Amerikaanse Neger en mulat zeer prijs stellen op een lichte huidkleur. Dat doet zich voor bij mensen die reeds zijn opgenomen in de Europees-koloniale samenleving. Blijkbaar voelen $\mathrm{zij}$, dat het nog niet ten volle is.

Het verschijnsel laat zich op sociale gronden verklaren. Maar misschien is de diepere grond, dat vele Negers voelen dat zij, als zelfbewuste zelfstandige persoonlijkheid bij de Blanken zijn achtergebleven. Hoewel de Afrikaanse Negerstaten en ook de Bosnegergemeenschappen een opmerkelijke prestatie hebben geleverd, is dat toch slechts in theocratisch verband geweest. Ook de aanleg voor bezetenheid, waarbij de zelfbewuste persoonlijkheid tijdelijk verdwijnt, toont dat er een verschil is tussen den Neger en den huidigen Blanke. Alles gemiddeld genomen; de individuele verschillen kunnen dit volkomen uitwissen.

Spreekt men over volken en rassen, dan heeft men het immer 
over gemiddelden. Dan echter valt niet te loochenen, dat er behalve in uiterlijke, ook in innerlijke eigenschappen, aanmerkelijke verschillen zijn. Het is beter hierbij het hatelijke „meer” en "minder" geheel terzijde te laten, en in beginsel aan te nemen dat elk volk en elk ras zijn eigen genie heeft. Het algemeen belang zou dan eigenlijk vorderen dat elk volk en elk ras de taak vervult waartoe het bijzonder geschikt is 1 ).

Men komt hier aan het vraagstuk of een geleide rassenpolitiek wenselijk zou wezen? Wij weten er echter te weinig van. Er zijn wel meningen: de Angelsaksers zijn voorstanders van raszuiverheid, zij het in den regel niet op zo overdreven wijze als onlangs de nationaal-socialisten. De Nederlanders daarentegen zijn op dit punt zeer vrijzinnig. Maar de zaak wordt doorkruist door nationale en andere invloeden, wat het nog moeilijker maakt.

Wat nationalisme betreft: de Negers zijn als slaaf in Amerika gekomen en ook na vrijlating burgers gebleven van de door Blanke kolonisten gestichte staatsgemeenschappen of gebiedsdelen. Met de Blanke samenleving in de wereld gaat het in deze eeuw niet al te best. Men kan zich afvragen of het wel mogelijk is een samenleving in stand te houden als het cement van gemeenschappelijke religie ontbreekt? Religie echter kan slechts bestaan als de betrokkene er iets bij beleeft. Dat is nog wel enigszins het geval bij de winti, obia en vudu der Amerikaanse Negers. Maar het ziet er toch dermate decadent uit, dat er geen toekomst meer in zal zitten.

1) Voor een onpartijdig oordeel zie men: O. Klinberg, Characteristics of the American Negro, New York \& London 1944. Dit werk citeert ook meningen van Neger-auteurs. 